\title{
PENGOPTIMALAN PRODUKSI BAWANG MERAH (Allium ascalonicum L.) DENGAN PEMANFAATAN PUPUK KANDANG AYAM
}

\author{
Lukman Nurahim ${ }^{1}$ dan Rina Alfina ${ }^{2}$ \\ Program Studi Teknologi Produksi Hortikultura Jurusan Budidaya Tanaman Pangan \\ Politeknik Pertanian Negeri Payakumbuh \\ Email: lukhmannisty1@gmail.com
}

\section{INTISARI}

Bawang merah (Allium ascalonicum L.) merupakan salah satu komoditi hortikultura yang banyak dibutuhkan oleh masyarakat tidak hanya sebagai pelengkap bumbu masakan tetapi juga mampu mengontrol kadar kolesterol dalam tubuh, mencegah pertumbuhan sel kanker, mengontrol kadar diabetes dalam tubuh dan sebagai bahan aromatik dalam tubuh. Banyaknya manfaat yang dimiliki bawang merah menyebabkan kebutuhan terhadap bawang merah mengalami peningkatan setiap tahunnya. Petani bawang merah saat ini umumnya bercocok tanam dengan menggunakan bahan anorganik. Penggunaan bahan anorganik secara terusmenerus akan merusak lingkungan. Penggunaan pupuk kandang ayam dalam budidaya bawang merah merupakan alternatif teknologi yang dapat diaplikasikan untuk mengurangi pemakaian bahan anorganik serta dapat meningkatkan produksi. Budidaya bawang merah ini dilakukan pada Proyek Usaha Mandiri (PUM) dengan tujuan menerapkan sistem pertanian yang berwawasan lingkungan dan berkelanjutan, mengoptimalkan produksi bawang merah dan menganalisis kelayakan usaha budidaya bawang merah di daerah Payakumbuh dan Kabupaten Limapuluh Kota. PUM dilaksanakan pada bulan Oktober 2015 sampai Januari 2016 di kebun percobaan Politeknik Pertanian Negeri Payakumbuh. Dari pelaksanaan PUM dapat disimpulkan bahwa hasil yang diperoleh sebanyak $29 \mathrm{~kg}$ dengan harga rata-rata Rp.25.172,41/kg, profitabilitas - 39,06 \% dan $R / C$ rasio 0,61 serta kegiatan PUM mengalami kerugian.

Kata kunci: Bawang merah, kondisi lingkungan, pupuk kandang ayam.

\section{ABSTRACT}

Onion (Allium ascalonicum L.) is one of the horticultural commodities needed by humans. Onion not only used as a spice in cooking but also to control cholesterol levels in the body, prevent the growth of cancer cells, control diabetes levels and as an aromatic ingredient in the body. Many benefits of onion cause the need for onions to increase every year. Onion farmers now generally grow crops using inorganic materials. Using inorganic materials continuously will damage the environment. The use of chicken manure in onion cultivation is an alternative technology that can be applied to reduce the use of inorganic materials and can increase production. The goal of an Independent Business Project (IBP) are to apply an environmentally sound and sustainable farming system, optimizing the production of onion, and analyzing the feasibility of onion cultivation in the Payakumbuh area and Limapuluh Kota Regency. IBP has been implemented in October 2015 to January 2016 in the experimental garden Polytechnic State Agricultural Payakumbuh. Implementation of the project gets results as much as $29 \mathrm{~kg}$ with an average price of Rp.25,172.41 / kg, profitability - 39.06\% and $R / C$ ratio of 0.6. This project suffered a loss.

\footnotetext{
${ }^{1}$ Mahasiswa Program Studi Teknologi Produksi Hortikuktura

${ }^{2}$ Staf Pengajar Program Studi Teknologi Produksi Hortikultura
} 


\section{PENDAHULUAN}

Bawang merah (Allium ascalonicum L.) merupakan family dari Amarillidaceae yang berasal dari Asia Tengah, yaitu sekitar Bangladesh, India, dan Pakistan. Negaranegara di Eropa Barat, Eropa Timur, dan Spanyol mengenal bawang merah pada abad ke delapan. Dari Eropa Barat, Eropa Timur, dan Spanyol, bawang merah menyebar hingga ke daratan Amerika dan Asia. Penyebaran ini tampaknya berhubungan dengan pemburuan rempah-rempah oleh bangsa Eropa ke wilayah timur yang kemudian berlanjut dengan pendudukan Kolonial di wilayah Indonesia (Rahayu dan Berlian, 2004).

Bawang merah merupakan salah satu komoditi hortikultura yang banyak dibutuhkan oleh masyarakat terutama sebagai pelengkap bumbu masakan, untuk menambah cita rasa dan kenikmatan makanan. Selain itu, bawang merah juga mengandung gizi dan senyawa yang tergolong zat non gizi serta enzim yang bermanfaat untuk terapi. Bawang merah merupakan tanaman umbi lapis, umbi tersebut dapat membentuk tunas baru, tumbuh dan membentuk umbi kembali. Karena sifat pertumbuhannya yang demikian maka dari satu umbi dapat membentuk rumpun tanaman yang berasal dari peranakan umbi.

Bawang merah pada umumnya ditanam pada musim kemarau, tetapi tidak tertutup kemungkinan untuk menanamnya pada musim hujan. Menanam bawang merah di luar musim tanam banyak gangguannya, ini disebabkan keadaan cuaca pada musim hujan kurang menguntungkan untuk pertumbuhan bawang merah.

Menanam bawang merah di luar musim tanam adalah salah satu kegiatan bercocok tanam yang menguntungkan bagi para petani bawang. Harga bawang merah pada musim hujan umumnya tinggi, dapat mencapai 4-5 kali harga bawang di musim panen, tetapi memiliki tingkat bahaya yang sangat tinggi. Hambatan petani dalam penanaman di musim hujan tersebut adalah melimpahnya air yang dapat menyebabkan unsur hara tercuci dengan cepat dan banyaknya serangan penyakit.

Badan Pusat Statistik (BPS) dan Direktorat Jenderal Holtikultura (DJH) menyebutkan bahwa produksi bawang merah di Indonesia dari tahun 2006 - 2010 selalu mengalami peningkatan yaitu sebesar 794.929 ton, 802.810 ton, 853.615 ton, 965.164 ton, dan 1.048.934 ton. Akan tetapi sepanjang tahun 2010 impor bawang merah di Indonesia tercatat sebesar 73.864 ton dan dalam tiga bulan pertama tahun 2011 impor bawang merah di Indonesia mencapai 85.730 ton. Hal itu membuktikan bahwa kebutuhan akan bawang merah di dalam negeri masih tinggi dibandingkan ketersediaannya.

Produksi bawang merah di daerah Sumatera pada tahun 2010 menurut Dinas Pertanian yang di kutip dari BPS 2011 adalah 16.236 ton, sedangkan kebutuhan bawang merah mencapai 66.940 ton. Salah satu penyebab utama rendahnya produksi di daerah Sumatera yaitu turunnya tingkat kesuburan tanah, karena penggunaan bahan kimia yang berlebihan tanpa disertai penggunaan bahan organik. Penggunaan bahan-bahan kimia mengakibatkan tanah menjadi keras, kurangnya porositas tanah, rendahnya daya ikat air, populasi dan aktifitas mikroba terganggu. Kondisi ini menghambat proses serapan air yang menyebabkan terganggunya metabolisme pada tanaman. Keadaan tanah yang seperti ini salah satunya dapat ditanggulangi dengan menggunakan bahan-bahan organik seperti pupuk kandang ayam.

Tujuan pelaksanaan Proyek Usaha Mandiri ini yaitu untuk menerapkan sistem pertanian yang berwawasan lingkungan dan berkelanjutan, mengoptimalkan produksi bawang merah dalam proyek usaha mandiri, dan menganalisis kelayakan usaha budidaya bawang merah di daerah Payakumbuh dan Kabupaten Lima Puluh Kota. 


\section{METODE PENELITIAN}

\section{Waktu dan Tempat}

Proyek usaha mandiri (PUM) dilaksanakan pada bulan Oktober 2015 sampai Januari 2016. Proyek ini dilakukan di kebun percobaan Politeknik Pertanian Negeri Payakumbuh.

\section{Alat dan Bahan}

Alat yang digunakan adalah cangkul, kored, garu, gembor, meteran, parang dan ember. Sedangkan bahan yang digunakan yaitu bibit bawang merah, pupuk kandang ayam, mulsa plastik hitam perak, tali rafia, abu gosok dan pupuk NPK mutiara.

\section{Prosedur Penelitian}

\section{Penyediaan Bibit}

Bibit bawang merah yang ditanam adalah bawang merah varietas Solok. Varietas ini merupakan varietas lokal yang dapat dipanen pada umur 55-75 hari setelah tanam. Ukuran bibit yang optimal adalah 3-4 g yang telah disimpan 2-3 bulan. Kebutuhan bibit dalam usaha ini yaitu lebih kurang $20 \mathrm{~kg} / 250 \mathrm{~m}^{2}$ yang langsung dibeli di distributor dari Alahan Panjang.

\section{Persiapan Lahan}

Pengolahan lahan dilakukan dengan membersihkan lahan dari gulma atau sisa-sisa tanaman sebelumnya. Tanah dicangkul dan dihaluskan, lalu dibuat bedengan dengan tinggi $30 \mathrm{~cm}$, lebar $1,2 \mathrm{~m}$ dan panjang $125 \mathrm{~m}$. Setelah pembentukan bedengan, dilakukan pengukuran $\mathrm{pH}$ tanah, karena $\mathrm{pH}$ tanah memenuhi syarat yang dibutuhkan bawang merah maka tidak dilakukan pengapuran.

\section{Pemberian Pupuk Kandang Ayam}

Pemberian pupuk kandang ayam dilakukan setelah pembuatan bedengan, dosis yang diberikan yaitu 20 ton/ha atau 500 $\mathrm{kg} / 250 \mathrm{~m}^{2}$. Pemberian pupuk kandang ayam dilakukan dengan cara menyebar kotoran ayam di atas bedengan secara merata. Hal ini bertujuan untuk efisiensi waktu pemberian kotoran ayam karena jarak tanam bawang merah yang dekat.

\section{Pemasangan Mulsa}

Pemasangan mulsa dilakukan setelah pemberian pupuk kandang ayam. Mulsa plastik dipasang pada permukaan bedengan. Agar mulsa tidak mudah lepas jika terkena angin maka pada bagian tepi ditancapkan potongan bambu yang ditipiskan. Pemasangan mulsa ini sebaiknya dilakukan pada siang hari ketika matahari sedang terik sehingga mulsa dapat ditarik dan dikembangkan secara maksimal.

\section{Pembuatan Lubang Tanam}

Lubang tanam dibuat dengan jarak $15 \mathrm{~cm}$ x $15 \mathrm{~cm}$ dengan kedalaman 2-3 cm. Pembuatan lubang tanam diawali dengan melubangi mulsa menggunakan kaleng susu.

\section{Penanaman Bibit}

Penanaman bibit dilakukan pada lubang tanam yaitu dengan memasukkan satu bibit pada satu lubang tanam. Bibit yang ditanam sebelumnya dipotong $1 / 3$ bagian atasnya dengan tujuan mempercepat dan menyeragamkan pertumbuhan tanaman. Bibit yang telah dipotong $1 / 3$ bagian dikering anginkan sehari sebelum penanaman. Cara penanaman bibit bawang merah yaitu masukkan bibit pada lubang tanam dengan gerakan seperti memutar sekrup, sehingga ujung umbi tampak rata dengan permukaan tanah. Tidak dianjurkan untuk menanam terlalu dalam, karena umbi mudah mengalami pembusukan. Setelah ditanam, lubang tanam disiram supaya tanah menjadi lembab.

\section{Pemupukan}

Pemupukan dasar menggunakan pupuk majemuk NPK Yara Mila Mutiara $480 \mathrm{~kg} / \mathrm{ha}$ atau $12 \mathrm{~kg} / 250 \mathrm{~m}^{2}$. Setengah dosis diberikan pada saat awal tanam, ditebar merata pada permukaan bedengan. Setengah dosis sisanya diberikan sebagai pupuk susulan ketika tanaman bawang merah berumur 4 minggu setelah tanam dengan pemberian perlubang tanaman.

\section{Pemeliharaan}

a. Penyulaman

Penyulaman dilakukan pada umur 4-9 hari setelah tanam dengan cara menanam kembali bibit yang tidak tumbuh atau busuk pada awal pertumbuhan, agar petumbuhan tanaman seragam dan populasi tanaman tidak berkurang.

b. Penyiraman

Tanaman bawang merah tidak menghendaki banyak hujan karena umbi dari bawang merah mudah busuk, selama pertumbuhannya tanaman bawang merah tetap membutuhkan air yang cukup. Penyiraman 
dilakukan sehari sekali, ketika keadaan tanah masih basah atau lembab tidak dilakukan penyiraman. Setelah tanaman berumur dua bulan, penyiraman dilakukan dua kali sehari. Pada umur ini tanaman bawang merah membutuhkan cukup banyak air untuk membentuk pertumbuhan umbi bawang merah.

b. Penyapuan

Penyapuan dilakukan dengan tangan pada pagi hari jika pada daun tanaman terdapat embun atau air setelah terjadi hujan, karena daun tanaman bawang merah tidak tahan dengan air yang dapat menyebabkan penyakit pada tanaman.

\section{c. Penyiangan}

Penyiangan dilakukan bersamaan dengan pupuk susulan, yaitu pada umur 4 minggu setelah tanam. Penyiangan pada lahan budidaya bawang merah dilakukan secara mekanik untuk membersihkan gulma yang kemungkinan dijadikan inang hama ulat bawang, menghindari terjadinya persaingan unsur hara, cahaya dan air. Dalam penyiangan harus dilakukan secara hatihati agar tidak merusak perakaran bawang merah. Penyiang gulma pada drainase dilakukan dengan menggunakan alat bantu cangkul atau kored, sedangkan pada lubang tanam gulma dicabut menggunakan tangan.

d. Pengendalian Hama dan Penyakit

Pengendalian hama dilakukan dengan mengambil dan membuangnya dengan tangan. Serangan hama yang sudah di batas ambang ekonomi dilakukan pengendalian dengan menggunakan pestisida. Sedangkan pada penyakit seperti layu, tanaman dicabut dan dibuang jauh dari lahan. Penyakit yang disebabkan oleh jamur dilakukan pengendalian dengan menggunakan pestisida.

\section{Panen dan Pasca Panen}

Panen dilakukan saat tanaman berumur 65-75 hari setelah tanam, dengan ciri-ciri tanaman hampir 60-90\% batang telah lemas, daun menguning, umbi lapis terlihat padat berisi, umbi mulai terlihat di permukaan tanah, dan warna kulit umbi mengkilat. Panen dilakukan dengan cara mencabut tanaman bersama daunnya dan diusahakan agar tanah yang menempel pada umbi dibersihkan.

Pasca panen dilakukan dengan melakukan pengeringan, pemotongan batang, pembersihan, dan penyimpanan.

\section{Pemasaran}

Umbi bawang merah kering yang telah dibersihkan dijual langsung ke masyarakat dengan cara mengecer. Harga penjualan disesuaikan dengan harga pasar, rata-rata $\mathrm{Rp}$ $24.500 / \mathrm{kg}$.

\section{HASIL DAN PEMBAHASAN}

\section{Tabel 1. Biaya Bahan}

\begin{tabular}{|c|c|c|c|c|c|}
\hline No & Bahan & Satuan & $\begin{array}{c}\text { Kebutu } \\
\text { han }\end{array}$ & $\begin{array}{c}\text { Harga } \\
\text { Satuan } \\
\text { (Rp) }\end{array}$ & $\begin{array}{c}\text { Biaya } \\
\text { (Rp) }\end{array}$ \\
\hline 1 & Bibit & $\mathrm{Kg}$ & 20 & 15.000 & 300.000 \\
\hline 2 & $\begin{array}{l}\text { Pupuk } \\
\text { Kandang } \\
\text { Ayam }\end{array}$ & $\mathrm{Kg}$ & 500 & 200 & 100.000 \\
\hline 3 & Tali Rapia & Glg & 1 & 2.000 & 2.000 \\
\hline 4 & МРPH & Bal & 1 & 180.000 & 180.000 \\
\hline 5 & NPK & $\mathrm{Kg}$ & 12 & 11.000 & 132.000 \\
\hline
\end{tabular}

Tabel 2. Biaya Tenaga Kerja

\begin{tabular}{|c|c|c|c|c|}
\hline NoJenis Kegiatan & $\begin{array}{l}\text { Sat } \\
\text { uan }\end{array}$ & $\begin{array}{l}\text { Kebut } \\
\text { uhan }\end{array}$ & $\begin{array}{c}\text { Harga } \\
\text { Satuan } \\
(\mathbf{R p})\end{array}$ & $\begin{array}{l}\text { Biaya } \\
\text { (Rp) }\end{array}$ \\
\hline $\begin{array}{ll}1 & \text { Persiapan } \\
& \text { Lahan }\end{array}$ & $\mathrm{HKO}$ & 3 & 50.000 & 150.000 \\
\hline $\begin{array}{l}2 \text { Pemasangan } \\
\text { MPPH }\end{array}$ & $\mathrm{HKO}$ & 0,5 & 50.000 & 25.000 \\
\hline $\begin{array}{l}3 \text { Pembuatan } \\
\text { lubang tanam }\end{array}$ & $\mathrm{HKO}$ & 0,5 & 50.000 & 25.000 \\
\hline $\begin{array}{l}4 \text { Persiapan Bibit } \\
\text { dan Penanaman }\end{array}$ & $\mathrm{HKO}$ & 1 & 50.000 & 50.000 \\
\hline 5 Penyiraman & $\mathrm{HKO}$ & 0,5 & 50.000 & 25.000 \\
\hline 6 Penyapuan & HKO & 0,25 & 50.000 & 12.500 \\
\hline $\begin{array}{l}7 \text { Penyiangandan } \\
\text { Penyulaman }\end{array}$ & HKO & 1 & 50.000 & 50.000 \\
\hline 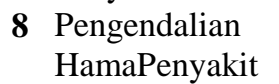 & $\mathrm{HKO}$ & 0.25 & 50.000 & 12.500 \\
\hline $\begin{array}{l}9 \text { Panen dan } \\
\text { Pasca Panen }\end{array}$ & $\mathrm{HKO}$ & 1 & 50.000 & 50.000 \\
\hline 10 Pemasaran & $\mathrm{HKO}$ & 0,5 & 50.000 & 25.000 \\
\hline & \multicolumn{2}{|c|}{ Jumlah } & \multicolumn{2}{|r|}{425.000} \\
\hline
\end{tabular}


Tabel 3. Biaya Alat

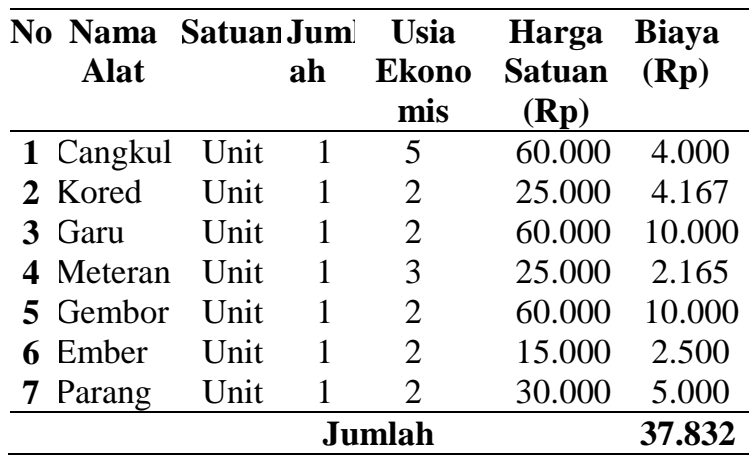

\section{Analisis Finanasial}

a. Biaya sewa lahan, biaya operasional dan non operasional

- Sewa Lahan

=Luas Lahanxsewa/tahunx lama pemakaian /tahun : 1 hektar

$=250 \mathrm{~m}^{2} \mathrm{x}$ Rp2.000.000 x 4/12:10.000 $\mathrm{m}^{2}$

$=\operatorname{Rp} 16.667$

- Biaya Operasional

= Biaya Bahan + Biaya tenaga Kerja

$=\mathrm{Rp} 714.000+\mathrm{Rp} 425.000$

$=\mathrm{Rp} 1.139 .000$

- Biaya Non Operasional

= Biaya Peyusutan Alat

$=\operatorname{Rp} 37.832$

b. Biaya Bunga Modal

$=15 \%$ (Biaya Operasional + Biaya Non Operasional + Biaya Sewa Lahan) $\mathrm{x}$ Musim Tanam/tahun

$=15 \%(\mathrm{Rp} 1.139 .000+\mathrm{Rp} 37.832+\mathrm{Rp} 16.667)$ $\mathrm{x} 3 / 12$

$=\mathrm{Rp} 44.756,21$

c. Biaya total lain-lain

= Biaya sewalahan + biaya bunga modal

$=\mathrm{Rp} 16.667+\mathrm{Rp} 44.756,21$

$=\mathrm{Rp} 61.423,21$

d. Biaya total (TC)

=Biaya operasional + biaya non operasional+ biaya total lain-lain

$=\mathrm{Rp} 1.139 .000+\mathrm{Rp} 37.382+\mathrm{Rp} 61.423,21$

$=\mathrm{Rp} 1.238 .225,21$

e. Proyeksi laba-rugi

$=$ penerimaan total $(\mathrm{TR})-$ biaya total $(\mathrm{TC})$

$=\operatorname{Rp} 147.000-\mathrm{Rp} 1.238 .225,21$
$=-\operatorname{Rp} 1.091 .255,21$

f. Profitabilitas

$$
=\frac{\mathrm{TR}-\mathrm{TCx}}{\mathrm{TC}} 100 \%
$$

TC

$=\underline{\operatorname{Rp~} 147.000-\operatorname{Rp~1.238.255,21~}} \times 100 \%$ Rp1.238.225,21

$=-88,12 \%(<15 \%$, proyek rugi $)$

g. R.C ratio

$=\underline{\mathrm{TR}}=\underline{\mathrm{Rp} 147.000}=0,188$

TCRp1.238.225,21

(>0,1, proyek layak)

h. BEP Harga

$=\underline{\mathrm{TC}}$

Hasil

$=\underline{\operatorname{Rp} 1 \cdot 1 \cdot 238 \cdot 225,21}$

$6 \mathrm{~kg}$

$=\operatorname{Rp} 206.375,87$

i. BEP Hasil

$=\underline{\mathrm{TC}}$

Harga $/ \mathrm{kg}$

$=\underline{\mathrm{Rp} 1.238 .225,21}$

$\operatorname{Rp} 24.500$

$=50,54 \mathrm{~kg}$

j. BEP Lahan

$=\underline{\mathrm{TC}} \mathrm{x}$ luas lahan

TR

$=\underline{R p 1.238 .225,21 \times} \times 250 \mathrm{~m}^{2}$

Rp 147.000

$=2.105,88 \mathrm{~m}^{2}$

Proyek usaha mandiri yang dilakukan memiliki produksi yang sangat rendah dibandingkan dengan produksi rata-rata Kabupaten Lima Puluh Kota 5 tahun terakhir. Bawang merah yang mampu diproduksi di proyek usaha mandiri hanya $6 \mathrm{~kg} / 250 \mathrm{~m}^{2}$ atau setara dengan $240 \mathrm{~kg} / \mathrm{ha}$, sedangkan produksi yang dimiliki Kabupaten Lima Puluh Kota yaitu 5,323 ton/ha. Banyak faktor yang mempengaruhi produksi bawang merah, antara lain kondisi lingkungan yang selalu berubah-ubah seperti kabut asap, kondisi lingkungan yang sangat kering dan kondisi lingkungan yang sangat basah.

Kondisi lahan yang disediakan untuk pelaksanaan proyek usaha mandiri tidak cocok 
dengan kondisi yang diinginkan bawang merah. Keadaan tanah yang sangat kering dan keras disertai dengan kabut asap yang tebal sehingga menyebabkan tidak adanya turun hujan. Tanah yang sangat keras dengan miskinnya ketersediaan air menghambat pertumbuhan bawang merah yang hanya memiliki perakaran dangkal sekitar $20 \mathrm{~cm}$. Perakaran bawang merah susah untuk berkembang karena tekstur dan struktur tanah yang tidak mendukung.

Keadaan lingkungan yang selalu berubah mamiliki pengaruh yang sangat besar terhadap pertumbuhan tanaman. Kondisi kekeringan yang dipengaruhi kabut asap tidak dapat diatasi dengan dilakukannya penyiraman terhadap tanaman. Selain itu, setelah terjadinya kondisi kering yang dialami tanaman, kondisi berbalik dengan tingginya tingkat curah hujan yang tidak diimbangi dengan adanya drainase yang baik menyebabkan terjadinya genangan atau kebanjiran pada lahan. Syaikhul (2013) memaparkan bahwa kelebihan air akan menyebabkan membesarnya ukuran sel, ukuran internode menjadi tidak normal, tanaman tidak kokoh, dan tidak terjadi pertumbuhan yang vigorous sehingga mudah diserang penyakit. Bila air yang tergenang selama beberapa hari dapat menyebabkan akar tidak dapat melaksanakan respirasi normal aerob namun terjadi respirasi anaerob. Keadaan seperti ini akan menyebabkan tingginya kadar alkohol dalam tubuh tanaman yang selanjutnya akan meracuni tanaman.

Kelebihan air juga menyebabkan beberapa hal yang merugikan, yaitu mempercepat proses pemiskinan hara dalam tanah akibat proses pencucian (perlin-dian/leaching) yang terjadi secara intensif, mempercepat proses perubahan horizon dalam tanah akibat terjadinya eluviasi dari lapisan tanah atas ke lapisan tanah bawah, kondisi jenuh air menjadikan ruang pori secara keseluruhan terisi air sehingga menghambat aliran udara ke dalam tanah, sehingga mengganggu respirasi dan serapan hara oleh akar tanaman, serta menyebabkan perubahan reaksi tanah dari reaksi aerob menjadi reaksi anaerob (Madjid, 2016).

Curah hujan yang dibutuhkan tanaman bawang merah yaitu 100-200 $\mathrm{mm} / \mathrm{bulan}$, sedangkan selama pertumbuhannnya curah hujan melebihi kebutuhan tersebut. Pada bulan
November - Desember curah hujan di daerah Kabupaten Lima Puluh Kota sangat tinggi yaitu $614,4 \mathrm{~mm} /$ bulan $-233,8 \mathrm{~mm} /$ bulan (Jakfarudin, 2016). Kondisi ini juga menyebabkan kerusakan pada bedengan dan hanyutnya tanah karena lokasi lahan yang berada pada drainase pembuangan air yang berasal dari berbagai tempat.

Proyek usaha mandiri yang dilakukan mengalami kerugian sebesar $\mathrm{Rp}$ 1.091.255 dengan penerimaan Rp.147.000 dan pengeluaran Rp 1.238.255. Jika dibandingkan perencanaan, usaha budidaya ini memiliki keuntungan yang cukup besar yaitu Rp. 1.661.053 dengan penerimaan Rp. 3.622.275 dan total biaya yang dikeluarkan yaitu Rp. 1.961.221,95. Kerugian yang besar disebabkan oleh sangat kecilnya jumlah produksi yang didapatkan dibanding pada perencanaan. Pada perencanaan produksi yang ingin dicapai sekitar $213 \mathrm{~kg}$ sedangkan pada realisasi hanya mampu diproduksi sebanyak $6 \mathrm{~kg}$.

Pada perencanaan budidaya bawang merah ini layak untuk dibudidayakan dengan profitabilitas $88,69 \%$ besar dari $15 \%$. Pelaksanaan budidaya juga akan mendapatkan keuntungan dilihat dari $\mathrm{R} / \mathrm{C}$ ratio yang lebih besar dari 1 yaitu mencapai 1,84. Berbeda halnya dengan perencanaan, realisasi budidaya ini mengalami banyak kendala sehingga profitabilitas tidak mampu melebihi $15 \%$ melainkan $-88,12 \%$ dan dengan $\mathrm{R} / \mathrm{C}$ ratio yang hanya 0,118 . Melihat kondisi tersebut, proses budidaya ini dikatakan mengalami kerugian cukup besar dan tidak layak untuk diusahakan.

Dalam usaha ini dapat dicapai BEP harga Rp. 206.375,87, BEP hasil 50,54 kg dan BEP lahan $2,105,88 \mathrm{~m}^{2}$. Kondisi menjadi harus lebih besar dibandingkan dengan perencanaan yang memiliki untung yang besar.

Keadaan lapangan yang tidak cocok dengan tanaman bawang merah dan kondisi lingkungan yang terserang kabut asap menghambat pertumbuhan tanaman bawang merah. Proses pertumbuhan berjalan lambat serta tanaman yang berhasil tumbuh memiliki pertumbuhan yang kurang baik disertai adanya serangan penyakit. Di tengah proses budidaya, tanaman banyak yang mati dan kemudian kondisi lingkungan berubah menjadi lebih baik dari kekeringan ke kondisi yang memiliki 
intensitas curah hujan yang sedang. Pada saat curah hujan yang memadai atau sedang tersebut dilakukan penyulaman untuk mengganti tanaman yang mati atau tidak tumbuh.

Pada umur satu minggu tanaman bawang merah menunjukan pertumbuhan yang sangat baik. Ketika tanaman tersebut berumur dua minggu setelah penanaman, cuaca mulai berubah, intensitas curah hujan menjadi sangat tinggi. Curah hujan yang sangat tinggi disertai kondisi drainase yang tidak baik dan saluran drainase tersebut merupakan saluran drainase dari berbagai tempat yang mengakibatkan lahan menjadi tergenang hingga menutupi bedengan, menyebabkan tanaman yang sebelumnya diberikan pupuk tidak akan berpengaruh terhadap pertumbuhan, karena pupuk yang di berikan tercuci bersamaan dengan lahan tergenang, bedengan menjadi rusak dan bawang ikut hanyut bersamaan dengan aliran air. Selain itu, letak lahan yang bersebelahan dengan drainase menjadikan bedengan tersebut sebagai pondasi untuk lahan yang lain agar aliran air tidak begitu besar sampai pada lahan lain. Hal ini mengakibatkan presentase kegagalan panen sangat tinggi

Setelah cukup umur untuk dipanen dan sesuai dengan kriteria panen, tanaman bawang merah dipanen dengan cara dicabut dan dibersihkan dari tanah yang melekat, selanjutnya dilakukan perlakuan pasca panen seperti pembersihan, pengeringan, dan sortasi. Hasil produksi bawang merah tersebut dijual langsung ke konsumen dengan mengecer.

Penyimpanan bawang merah yang baik harus memperhatikan beberapa faktor meliputi gudang, temperatur, kelembaban ruangan, dan keadaan bawang merah itu sendiri. Dengan teknik yang benar, bawang merah dapat disimpan selama 4 sampai 6 bulan.

\section{KESIMPULAN DAN SARAN}

Kesimpulan yang dapat diambil dari proyek usaha mandiri yang dilakukan adalah:

1. Proyek yang dilakukan mengalami kerugian sebesar Rp.1.091.255 dengan profitabilitas $88,12 \%$ dan R/C Ratio 0,118

2. Pemanfaatan pupuk kandang ayam belum mampu mengoptimalkan produksi bawang merah karena keadaan lingkungan yang tidak mendukung

Saran - saran yang perlu diperhatikan dalam budidaya bawang merah yaitu:

1. Menganalisis kondisi lingkungan yang sesuai atau tidaknya dilakukan budidaya bawang merah

2. Memilih lokasi yang tepat untuk dilakukannya budidaya bawang merah

\section{DAFTAR PUSTAKA}

Jakfarudin. 2016. Curah hujan 2015. Politeknik Pertanian Negeri Payakumbuh. 17 Januari 2016

Madjid. A. 2016. Fisika Tanah. http://bloghamdy.wordpress.com. 23 Januari 2016

Rahayu, E. dan Berlian. 1999. Budidaya Bawang Merah (A. ascalonicum L.). Sinar Baru, Bandung.

Syakhul. 2013. Pengaruh Pemberian Kotoran Ayam terhadap Pertumbuhan Tanaman jagung. http://www.muhammad-syakhulfisip12-web-unair.ac.id 